\title{
Available lysine and digestible amino acid contents of proteinaceous foods of India
}

\author{
Shane M. Rutherfurd ${ }^{1 *}$, Kiran Bains ${ }^{2}$ and Paul J. Moughan ${ }^{1}$ \\ ${ }^{1}$ Riddet Institute, Massey University, Palmerston North, New Zealand \\ ${ }^{2}$ Food and Nutrition, Punjab Agricultural University, Ludbiana-141004, Punjab, India \\ (Submitted 27 July 2011 - Final revision received 9 October 2011 - Accepted 18 November 2011)
}

\section{Abstract}

Cereals and legumes are staple foods in India and are limiting in lysine and sulphur amino acids, respectively. Available lysine loss, due to Maillard-type reactions that may occur during food preparation, exacerbates the problem of lysine deficiency particularly in cereals. Consequently, determining the contents of digestible essential amino acids, particularly lysine, is important. True ileal digestibilities of most amino acids (including total and reactive lysine) were determined for ten food ingredients and eleven foods commonly consumed in India. Semi-synthetic diets each containing either an ingredient or the prepared food as the sole protein source were formulated to contain $100 \mathrm{~g} \mathrm{~kg}^{-1}$ protein $\left(75 \mathrm{~g} \mathrm{~kg}^{-1}\right.$ for rice-based diets) and fed to growing rats. Titanium dioxide was included as an indigestible marker. Digesta were collected and the amino acid content (including reactive lysine) of diets and ileal digesta determined. Available (digestible reactive) lysine content ranged from $1 \cdot 9-15 \cdot 4 \mathrm{~g} \mathrm{~kg}^{-1}$ and $1 \cdot 8-12 \cdot 7 \mathrm{~g} \mathrm{~kg}^{-1}$ across the ingredients and prepared foods respectively. True ileal amino acid digestibility varied widely both across ingredients and prepared foods for each amino acid (on average 60-92\%) and across amino acids within each ingredient and prepared food (overall digestibility 31-96\%). Amino acid digestibility was low for many of the ingredients and prepared foods and consequently digestibility must be considered when assessing the protein quality of poorer quality foods. Given commonly encountered daily energy intakes for members of the Indian population, it is estimated that lysine is limiting for adults in many Indian diets.

Key words: Available lysine: Amino acids: India: Protein: Protein quality

India, like many other developing countries has not as yet eliminated the problem of under-nourishment in its poorer communities particularly with respect to protein. In these communities protein intakes tend to be low, and to exacerbate the problem Indian diets are generally cereal and legume based, the proteins of which tend to be more poorly digested than North American protein-based foods $(57-75 \%$ versus 88-94\%), largely due to the presence of high levels of insoluble fibre and anti-nutritional factors ${ }^{(1)}$. Cereals tend to be limiting in lysine while legumes are limiting in sulphur containing amino acids.

Ensuring food and nutritional security is a challenge for India, given its large population and high levels of poverty and malnutrition. National Nutrition Monitoring Bureau of India (NNMB) data have revealed a gradual decline in daily per capita intake of protein from $62.9 \mathrm{~g}$ in $1975-1979$ to $48.8 \mathrm{~g}$ in 2004-2005. In countries like India, where dietary amino acid supply may potentially limit protein metabolism, it is imperative to accurately monitor the dietary supply of 'available amino acids' in relation to the dietary requirement ${ }^{(2)}$. Consequently, it is essential to have a fundamental understanding of the digestible amino acid content of Indian foods and the extent to which the digestible amino acids meet the requirements of people in India. Protein digestibility-corrected amino acid score (PDCAAS), scores proteins based on their ability to meet the deemed amino acid requirement of humans for the first limiting amino acid and in the case of cereal-based diets that is likely to be lysine.

While the amino acid composition of many foods consumed in developing countries, including India, is known there is scant data about the digestibility of those amino acids and it is important that this gap in knowledge be addressed. Currently, PDCAAS uses faecal nitrogen digestibility values to correct amino acid scores to PDCAAS values. However, a single nitrogen digestibility value may not reflect the digestibility of all dietary amino acids ${ }^{(2)}$. Moreover, faecal amino acid digestibility values are often higher than ileal amino acid digestibility values, particularly for poorly digested protein sources ${ }^{(2,3)}$. Consequently, PDCAAS values may be more accurate when derived using true ileal amino acid digestibility values as opposed to faecal nitrogen digestibility values ${ }^{(4,5)}$.

*Corresponding author: S. M. Rutherfurd, fax +646350 5655, email S.M.Rutherfurd@massey.ac.nz 
Lysine is of particular interest since it is often first limiting in cereal-based diets and is susceptible to chemical modification during processing or cooking to form nutritionally unavailable derivatives ${ }^{(4,6)}$. Furthermore, lysine intakes have been shown to be marginal in low socio-economic group Indians ${ }^{(7,8)}$, which is of even greater concern given that the daily requirement for lysine has been shown to be approximately $30 \mathrm{mg} \mathrm{kg}^{-1} \mathrm{day}^{-1}$ for healthy Indian men ${ }^{(7)}$ or higher ( $44 \mathrm{mg} \mathrm{kg}^{-1} \mathrm{day}^{-1}$ ) where there is chronic undernourishment ${ }^{(8)}$. This value is more than double the requirement estimate laid out in 1985 by the WHO/FAO/UNU expert consultation group. Values for digestible lysine based on true ileal digestible total lysine are likely to overestimate the nutritional value of foods and food ingredients that have been processed or cooked. Instead true ileal digestible reactive lysine provides a more accurate measure of available lysine in such foods ${ }^{(4)}$. A method has been developed ${ }^{(9,10)}$ that allows the accurate determination of the available lysine (true ileal digestible reactive lysine) content of processed foods (Biolysine ${ }^{\mathrm{TM}}$ ). The objective of this study was to determine true ileal amino acid digestibility and available (digestible reactive) lysine contents for a range of typical cereal- and legume-based foods from India.

\section{Materials and methods}

\section{Samples}

Ten raw ingredients (wheat flour, rice, maize flour, black gram beans, refined flour, mung beans, lentils, chickpeas, kidney beans and pigeon peas) and eleven prepared foods (wheat roti, cooked rice, maize roti, dosa, idli, naan, mung dal, lentil dal, sambar, chickpea curry and rajmah) were each collected from six households selected in the Punjab region of India. The raw ingredients and prepared foods were pooled across households, freeze dried and ground using a standard kitchen food processor. The dried samples were then air freighted to Massey University, New Zealand where they were further ground through a $1 \mathrm{~mm}$ mesh and stored at $-20^{\circ} \mathrm{C}$ prior to analysis. The ingredients used to prepare the food dish are shown in Table 1.

\section{Preparation of 0.6M O-methylisourea solution}

A $0.6 \mathrm{M}$ O-methylisourea solution was prepared as described by Moughan and Rutherfurd ${ }^{(9)}$.

\section{Digestibility study}

Ethics approval for the animal trial was obtained from the Animal Ethics Committee, Massey University, Palmerston North, New Zealand. Male Sprague-Dawley rats of approximately $200 \mathrm{~g}$ bodyweight were housed individually in stainless steel wire-bottomed cages in a room maintained at $22 \pm 2{ }^{\circ} \mathrm{C}$ with a $12 \mathrm{~h}$ light/dark cycle. Twenty one semi-synthetic test diets were formulated. The crude protein content of the raw ingredients and prepared foods ranged from 77 to $279 \mathrm{~g} \mathrm{~kg}^{-1}$ DM. For samples that had a crude protein content
Table 1. Ingredients in the prepared foods.

\begin{tabular}{ll}
\hline Food & Ingredients \\
\hline $\begin{array}{l}\text { Cereal-based } \\
\text { Wheat roti }\end{array}$ & Wheat flour, water \\
Maize roti & Maize flour, water \\
Boiled rice & Rice, water \\
Naan & Refined wheat flour, oil \\
Legume-based & Chickpeas, water, onion, garlic, tomatoes, salt, \\
Chickpea curry & chillies and spices \\
Lentil dal & Lentils (dehusked and split), water, salt, \\
& red chillies and spices. Onion and \\
garlic (optional) & Mung beans (dehusked and split), water, oil, \\
Mung dal & salt, red chillies and spices. Onion and \\
& garlic (optional) \\
Rajmah & Kidney beans, water, onion, garlic, tomatoes, \\
salt, chillies and spices
\end{tabular}

less than $100 \mathrm{~g} \mathrm{~kg}^{-1}$, the diets consisted of the raw ingredient or prepared food, a proprietary vitamin mix $\left(50 \mathrm{~g} \mathrm{~kg}^{-1}\right)$, a proprietary mineral mix $\left(50 \mathrm{~g} \mathrm{~kg}^{-1}\right)$ and an indigestible marker titanium dioxide $\left(3 \mathrm{~g} \mathrm{~kg}^{-1}\right)$. For the remainder of the foods, diets were prepared by adding a proprietary vitamin mix, a proprietary mineral mix and an indigestible marker (titanium dioxide) to each of the foods and then diluting as appropriate with a mixture of soybean oil, purified cellulose, sugar and cornstarch in ratios of 10:5:15:70 to reduce the crude protein content to $100 \mathrm{~g} \mathrm{~kg}^{-1}$. The concentrations of vitamin mix, mineral mix and titanium dioxide in the final diets were $50 \mathrm{~g} \mathrm{~kg}^{-1}$, $50 \mathrm{~g} \mathrm{~kg}^{-1}, 3 \mathrm{~g} \mathrm{~kg}^{-1}$ respectively. A basal diet containing $100 \mathrm{~g} \mathrm{~kg}^{-1}$ protein was also formulated, using casein as the sole protein source, to meet the nutritional requirements for the growing rat for all nutrients except protein ${ }^{(11)}$. The latter diet contained $118 \mathrm{~g} \mathrm{~kg}^{-1}$ lactic casein, $50 \mathrm{~g} \mathrm{~kg}^{-1}$ proprietary vitamin premix, $50 \mathrm{~g} \mathrm{~kg}^{-1}$ proprietary mineral premix, $100 \mathrm{~g} \mathrm{~kg}^{-1}$ soybean oil, $100 \mathrm{~g} \mathrm{~kg}^{-1}$ sucrose, $50 \mathrm{~g} \mathrm{~kg}^{-1}$ purified cellulose and $529 \mathrm{~g} \mathrm{~kg}^{-1}$ cornstarch. Over the first eleven days of the 14-day experimental period, all the rats were fed the basal casein-based diet. The rats were then randomly allocated to the test diets such that there were five animals per diet and the animals were fed their respective test diets for a further three days. The test diets were not fed for the entire experimental period as they may not have met the rat's requirement for all nutrients. On each day, each rat had unrestricted access to its respective diet from 09.00 hours to 12.00 hours. Water was available at all times. On the final day of the study, between three and four hours after the start of feeding, the rats were asphyxiated using carbon dioxide gas and then decapitated. The stomach contents were checked for faecal matter and no sign of coprophagy was observed. The twenty centimetres of ileum immediately anterior to the ileo-caecal junction was dissected out. 
The dissected ileum was washed with distilled deionised water to remove any blood and hair and carefully dried on an absorbent paper towel. The digesta were gently flushed from the ileum section with distilled deionised water from a syringe. The digesta were then freeze-dried ready for chemical analysis.

\section{Chemical analysis}

Dry matter, ash, crude protein, crude fibre and total fat were determined according to the methods described by $\mathrm{AOAC}^{(12)}$. Protein content was estimated from the nitrogen content using a nitrogen to protein conversion factor of $6 \cdot 25$.

Amino acid contents were determined in duplicate five mg ingredient, prepared food and ileal digesta samples and quadruplicate five $\mathrm{mg}$ diet samples following hydrolysis in $6 \mathrm{M}$ glass-distilled $\mathrm{HCl}$ containing $0.1 \%$ phenol for $24 \mathrm{~h}$ at $110 \pm 2^{\circ} \mathrm{C}$ in evacuated sealed tubes. The liberated amino acids were derivatised with $o$-phthalaldehyde (OPA) (proline was not detected in the assay as it does not react with OPA). The derivatives were then separated on an Agilent 1200SL HPLC system equipped with a $C_{18}$ reverse-phase HPLC column and quantified using fluorescence detection (excitation $\lambda 338 \mathrm{~nm}$, emission $\lambda 450 \mathrm{~nm}$ ). Proline was detected using Accutag derivatisation (Waters Millipore, Milford, Ma) and fluorescence detection (excitation $\lambda 245 \mathrm{~nm}$, emission $\lambda 395 \mathrm{~nm}$ ). Cysteine and methionine were determined using performic acid oxidation followed by $\mathrm{HCl}$ acid hydrolysis as described above and quantified using Accutag derivatisation (Waters Millipore, Milford, Ma) and fluorescence detection. Tryptophan was determined using alkali hydrolysis in $4.5 \mathrm{M} \mathrm{NaOH}$ containing $5 \%(\mathrm{w} / \mathrm{v})$ maltodextrin at $110 \pm 2^{\circ} \mathrm{C}$ for $20 \mathrm{~h}$. Tryptophan was then quantified using absorbance at $280 \mathrm{~nm}$. 5-methyl tryptophan was used as an internal standard. The weight of each amino acid was calculated using free amino acid molecular weights. It should be noted that for some rats there was insufficient digesta material for the determination of methionine, cysteine and tryptophan.

Reactive lysine contents were determined in duplicate five $\mathrm{mg}$ ingredient, prepared food, digesta and diet samples after guanidination by incubation for seven days in $0.6 \mathrm{M}$ O-methylisourea, $\mathrm{pH} 10.6$ ( $\mathrm{pH} 11.0$ for the digesta samples), at $21 \pm 2^{\circ} \mathrm{C}$ in a shaking waterbath, with a reagent to lysine ratio greater than $1000^{(9)}$. After incubation, the samples were dried using a Speedvac concentrator (Savant Instruments, Inc, Farmingdale, NY, USA) and analysed for homoarginine content using a Waters ion-exchange HPLC system, utilising post-column OPA derivatisation and detection using fluorescence (excitation $\lambda 338 \mathrm{~nm}$, emission $\lambda 450 \mathrm{~nm}$ ), following hydrolysis as described above for the other amino acids.

The titanium contents of the diet and ileal digesta samples were determined in duplicate based on the method of Short et al. ${ }^{(13)}$. Samples were ashed before being digested in $60 \%$ (v/v) sulphuric acid and then incubated with $30 \%$ hydrogen peroxide and the absorbance read at $405 \mathrm{~nm}$.

\section{Data Analysis}

Ileal amino acid (AA) flows were calculated using the following equation (units are $\mu \mathrm{gg}^{-1}$ dry matter (DM)):

$$
\text { Ileal AA flow ( } \mu \mathrm{gg}^{-1} \text { dry matter intake (DMI)) }
$$

$=$ AA concentration in ileal digesta

$\times$ Dietary titanium/Ileal titanium

True ileal amino acid digestibility ${ }^{1}$ was calculated as follows (units are $\mu \mathrm{gg}^{-1} \mathrm{DMI}$ ):

$$
\begin{aligned}
& \text { True digestibility }(\%) \\
& =[\text { Dietary AA intake }-(\text { Ileal AA flow } \\
& \left.\left.\quad-\text { Endogenous AA flow }{ }^{2}\right)\right] / \text { Dietary AA intake } \times 100
\end{aligned}
$$

${ }^{1}$ True ileal glycine digestibility values were not calculated since the enzyme hydrolysed casein/ultrafiltration method underestimates endogenous ileal glycine losses.

${ }^{2}$ Based on endogenous amino acid flows for the growing rat as reported by Rutherfurd and Moughan ${ }^{(14)}$ and based on the enzyme hydrolysed casein/ultrafiltration method ${ }^{(15)}$.

True ileal reactive lysine (RL) digestibility was calculated as follows (units are $\mu \mathrm{gg}^{-1} \mathrm{DMI}$ ):

$$
\begin{aligned}
& \text { True ileal RL digestibility }(\%) \\
& =\left[\text { Dietary } \mathrm{RL}^{1} \text { intake }-\left(\text { Ileal RL }{ }^{1}\right. \text { flow }\right. \\
& \left.\left.\quad-\text { Endogenous lysine flow }{ }^{2}\right)\right] / \text { Dietary }^{R L^{1}} \text { intake } \times 100
\end{aligned}
$$

\footnotetext{
${ }^{1}$ Reactive lysine determined using the guanidination method.

${ }^{2}$ Based on the endogenous lysine flow reported by Rutherfurd and Moughan ${ }^{(14)}$ where for the enzyme hydrolysed casein/ultrafiltration method ${ }^{(15)}$ endogenous reactive lysine is equivalent to endogenous total lysine.

True ileal digestible reactive lysine content of the foods was calculated as follows:

$$
\begin{aligned}
= & \text { Reactive lysine content of the food }\left(\mathrm{g} \mathrm{kg}^{-1}\right) \\
& \times \text { True ileal reactive lysine digestibility }(\%)
\end{aligned}
$$$$
\text { True ileal digestible reactive lysine content }\left(\mathrm{g} \mathrm{kg}^{-1}\right)
$$

True ileal digestible amino acid content of the food was calculated as follows:

$$
\begin{aligned}
& \text { True ileal digestible amino acid content of the food }\left(\mathrm{g} \mathrm{kg}^{-1}\right) \\
& =\text { Amino acid content of the food }\left(\mathrm{g} \mathrm{kg}^{-1}\right) \\
& \quad \times \text { True ileal amino acid digestibility }(\%)
\end{aligned}
$$

The amino acid digestibility data were subjected to a one-way analysis of variance for each amino acid singly (GLM Procedure) $^{(16)}$. 


\section{Results}

The determined proximate composition of the ten Indian food ingredients and eleven common Indian food dishes prepared from similar ingredients is presented in Table 2. Crude protein ranged from 77 to 279 , crude fibre from 7 to 71 , total fat from 11 to 154 and ash from 3 to $64 \mathrm{~g} \mathrm{~kg}^{-1} \mathrm{DM}$ across ingredients and prepared foods. The nitrogen free extractive (NFE) ranged from 576 to $884 \mathrm{~g} \mathrm{~kg}^{-1} \mathrm{DM}$ and demonstrated as expected, that carbohydrates were the main chemical component of the foods tested.

The true ileal digestible reactive (available) lysine content varied markedly across ingredients and prepared foods from $1.9 \mathrm{~g} \mathrm{~kg}^{-1} \mathrm{DM}$ for rice to $15.4 \mathrm{~g} \mathrm{~kg}^{-1} \mathrm{DM}$ for lentils for the ingredients and $1.8 \mathrm{~g} \mathrm{~kg}^{-1} \mathrm{DM}$ for maize roti to $12 \cdot 7 \mathrm{~g} \mathrm{~kg}^{-1} \mathrm{DM}$ for lentil dal for the prepared foods (Table 3). For the cereal ingredients and cereal-based prepared foods the available lysine content ranged from $1.9 \mathrm{~g} \mathrm{~kg}^{-1} \mathrm{DM}$ for rice to $3 \cdot 1 \mathrm{~g} \mathrm{~kg}^{-1} \mathrm{DM}$ for wheat flour for the ingredients and from $1.8 \mathrm{~g} \mathrm{~kg}^{-1} \mathrm{DM}$ for maize roti to $2.7 \mathrm{~g} \mathrm{~kg}^{-1} \mathrm{DM}$ for wheat roti for the prepared foods. For the legume ingredients and legume-based prepared foods the available lysine content ranged from $10.3 \mathrm{~g} \mathrm{~kg}^{-1} \mathrm{DM}$ for pigeon peas to $15.4 \mathrm{~g} \mathrm{~kg}^{-1}$ $\mathrm{DM}$ for lentils for the ingredients and $9.7 \mathrm{~g} \mathrm{~kg}^{-1} \mathrm{DM}$ for chickpea curry to $12.7 \mathrm{~g} \mathrm{~kg}^{-1} \mathrm{DM}$ for lentil dal for the prepared foods. For the prepared foods containing both cereals and legumes the available lysine ranged from $4 \cdot 2 \mathrm{~g} \mathrm{~kg}^{-1} \mathrm{DM}$ for dosa to $4.9 \mathrm{~g} \mathrm{~kg}^{-1} \mathrm{DM}$ for idli.

The true ileal digestible total lysine content was also determined and compared with the true ileal digestible reactive (available) lysine content (Table 3). For seven of the eleven prepared foods, true ileal digestible total lysine significantly $(P<0.05)$ overestimated true ileal digestible reactive (available) lysine content. This overestimation ranged from $1 \%$ for lentil dal to $27 \%$ for idli with the mean overestimation being $12 \%$. For the other prepared foods, cooked rice, maize roti, rajmah and chickpea curry there was no significant difference $(P>0.05)$ between digestible total lysine and digestible reactive lysine contents. For the ingredients, there was no significant $(P>0.05)$ difference between digestible total and reactive lysine contents for most of the ingredients. The exceptions were wheat flour, rice, kidney beans and pigeon peas where for wheat flour, kidney beans and pigeon peas digestible total lysine significantly $(P<0.05)$ overestimated digestible reactive (available) lysine by between 6 and $12 \%$.

The true ileal digestibilities of amino acids (including reactive lysine) for the eleven commonly prepared Indian foods and the ten Indian food ingredients are given in Table 4. The overall true ileal amino acid digestibility determined across all amino acids for each food ingredient ranged from $31 \%$ for black gram beans to $96 \%$ for wheat flour with an overall mean digestibility across all ingredients of $77 \%$. For the prepared foods, overall amino acid digestibility ranged from $67 \%$ for rajmah to $95 \%$ for lentil dal with a mean overall amino acid digestibility calculated across all foods of $86 \%$. The least digestible amino acid across all the prepared foods was cysteine (mean value of $69 \%$ ) and the most digestible amino acids were lysine and leucine (mean value of $92 \%$ ). For the ingredients, the least digestible amino acid was aspartic acid

Table 2. Determined nutrient composition ${ }^{1}\left(\mathrm{~g} \mathrm{~kg}^{-1} \mathrm{DM}\right)$ of the eleven prepared Indian foods and ten Indian food ingredients.

\begin{tabular}{|c|c|c|c|c|c|}
\hline & Crude protein ${ }^{2}$ & Crude fibre & Total fat & Ash & $\mathrm{NFE}^{3}$ \\
\hline \multicolumn{6}{|l|}{ Prepared Indian food } \\
\hline Wheat roti & 124 & 23 & 32 & 17 & 821 \\
\hline Cooked rice & 77 & 9 & 11 & 5 & 884 \\
\hline Maize roti & 104 & 25 & 58 & 15 & 811 \\
\hline Dosa & 121 & 12 & 94 & 13 & 762 \\
\hline Idli & 146 & 11 & 19 & 16 & 805 \\
\hline Naan & 123 & 7 & 59 & 6 & 793 \\
\hline Mung dal & 213 & 66 & 102 & 64 & 612 \\
\hline Lentil dal & 228 & 31 & 108 & 45 & 601 \\
\hline Sambar & 212 & 28 & 101 & 52 & 602 \\
\hline Chickpea curry & 187 & 64 & 154 & 51 & 600 \\
\hline $\begin{array}{l}\text { Rajmah } \\
\text { Indian food ingredient }\end{array}$ & 233 & 65 & 74 & 53 & 629 \\
\hline Wheat flour & 138 & 24 & 30 & 16 & 755 \\
\hline Rice & 77 & 9 & 11 & 3 & 794 \\
\hline Maize flour & 108 & 21 & 57 & 14 & 752 \\
\hline Black gram beans & 269 & 17 & 23 & 37 & 602 \\
\hline Refined flour & 135 & 11 & 19 & 6 & 730 \\
\hline Mung beans & 249 & 71 & 22 & 38 & 598 \\
\hline Lentils & 274 & 21 & 21 & 20 & 618 \\
\hline Chickpeas & 265 & 55 & 58 & 32 & 590 \\
\hline Kidney beans & 279 & 61 & 28 & 41 & 576 \\
\hline Pigeon peas & 256 & 24 & 29 & 41 & 604 \\
\hline
\end{tabular}

${ }^{1}$ Analysis was conducted in duplicate.

${ }^{2}$ Protein content was estimated from the nitrogen content using a nitrogen to protein conversion factor of 6.25.

${ }^{3}$ Nitrogen free extractive was calculated as follows (units are $\mathrm{g} \mathrm{kg}^{-1}$ ):

Nitrogen free extractive $\left(\mathrm{g} \mathrm{kg}^{-1} \mathrm{DM}\right)=$ Total sample weight $-($ Moisture + Ash + Crude protein + Crude fibre + Ether extract) 
Table 3. Mean $(n=5)$ true ileal digestible total and reactive (available) lysine contents ${ }^{1}\left(\mathrm{~g} \mathrm{~kg}^{-1} \mathrm{DM}\right)$ for the eleven prepared Indian foods and ten Indian food ingredients.

\begin{tabular}{|c|c|c|c|c|}
\hline & \multicolumn{2}{|c|}{ Digestible lysine } & \multirow{2}{*}{$\begin{array}{l}\text { Overall } \\
\text { SE }\end{array}$} & \multirow{2}{*}{$\begin{array}{c}\text { Statistical } \\
\text { Significance }\end{array}$} \\
\hline & Total $^{2}$ & Reactive $^{3}$ & & \\
\hline \multicolumn{5}{|l|}{ Prepared Indian food } \\
\hline Wheat roti & 2.95 & $2 \cdot 66$ & 0.02 & 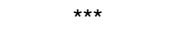 \\
\hline Cooked rice & 2.00 & 1.98 & 0.03 & NS \\
\hline Maize roti & 1.74 & 1.82 & 0.02 & NS \\
\hline Dosa & 4.85 & 4.21 & 0.07 & $\star \star$ \\
\hline Idli & $6 \cdot 22$ & 4.90 & 0.08 & 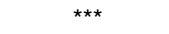 \\
\hline Naan & 2.59 & $2 \cdot 20$ & 0.06 & ** \\
\hline Mung dal & $12 \cdot 37$ & $11 \cdot 38$ & 0.07 & 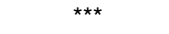 \\
\hline Lentil dal & $12 \cdot 81$ & $12 \cdot 65$ & 0.07 & 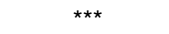 \\
\hline Sambar & 11.47 & $11 \cdot 15$ & 0.11 & * \\
\hline Chickpea curry & $9 \cdot 81$ & $9 \cdot 66$ & 0.11 & NS \\
\hline $\begin{array}{l}\text { Rajmah } \\
\text { Indian food ingredient }\end{array}$ & $10 \cdot 13$ & $10 \cdot 25$ & 0.23 & NS \\
\hline Wheat flour & 3.35 & $3 \cdot 11$ & 0.04 & * \\
\hline Rice & 1.87 & 1.92 & 0.03 & * \\
\hline Maize flour & $2 \cdot 27$ & $2 \cdot 34$ & 0.03 & NS \\
\hline Black gram beans & 6.03 & 7.00 & 0.80 & NS \\
\hline Refined flour & $2 \cdot 19$ & $2 \cdot 18$ & 0.02 & NS \\
\hline Mung beans & 12.57 & 11.96 & 0.37 & NS \\
\hline Lentils & $15 \cdot 20$ & $15 \cdot 42$ & 0.22 & NS \\
\hline Chickpeas & $15 \cdot 27$ & $15 \cdot 12$ & 0.15 & NS \\
\hline Kidney beans & 11.33 & $10 \cdot 66$ & 0.35 & $\star \star$ \\
\hline Pigeon peas & 11.68 & $10 \cdot 32$ & 0.28 & $\star \star \star$ \\
\hline
\end{tabular}

${ }^{1}$ The true ileal digestibility values used to calculate the true ileal digestible amino acid content were determined after correction for endogenous lysine flow determined using the enzyme hydrolysed casein/ultrafiltration method ${ }^{(15)}$ and using values as reported by Rutherfurd and Moughan ${ }^{(14)}$.

${ }^{2}$ Determined based on the analysis of total lysine in diet and digesta of rats fed the experimental diets.

${ }^{3}$ Determined based on the analysis of reactive lysine (guanidination reaction) in diet and digesta of rats fed the experimental diets.

${ }^{4}$ NS Not significant $P>0.05,{ }^{*} 0.05>P>0.01,{ }^{\star *} 0.01>P>0.001,{ }^{* \star *} P<0.001$.

(mean value of $60 \%$ ) and the most digestible was methionine (mean value of $89 \%$ ).

The true ileal digestible amino acid contents of the materials is presented in Table 5. There was considerable variation in the digestible amino acid content across both the prepared foods and food ingredients, with on average a 4.2- and $5 \cdot 0$-fold range in digestible amino acid contents across foods and amino acids for the prepared foods and ingredients respectively.

\section{Discussion}

The lysine intake of people in India, particularly children, is likely to be marginal, because firstly, food intake is generally low (17). Secondly, cereals and legumes tend to be staple foods for many Indians ${ }^{(17)}$ and cereals are low in lysine while legume intake relative to cereals tends to be low ${ }^{(18)}$. Thirdly, lysine is prone to undergo chemical modification when foods undergo heat processing (such as cooking) to form Maillard-type products which are generally nutritionally unavailable and will therefore further reduce the available lysine content. In this study, the available content of lysine and the ileal digestible amounts of other amino acids were determined in eleven commonly prepared Indian foods and ten Indian food ingredients.
Overall, true ileal digestible total lysine overestimated available lysine (true ileal digestible reactive lysine) for more than half the prepared foods and just under half of the food ingredients and in many cases this overestimation was large ( $>8 \%$ for seven of the prepared foods and ingredients). This is consistent with previous results ${ }^{(19-21)}$ and given that the available lysine assay $\left(\right.$ Biolysine $^{\mathrm{TM}}$ ) only requires a different step in the chemical analysis rather than a separate bioassay, this method should be the preferred one for determining lysine availability in foods. The traditional (total lysine based) ileal digestibility assay will lead to considerable error for some foods.

There was considerable variation in the available lysine content of the Indian food ingredients and prepared foods with 8-fold differences in the available lysine content across the ingredients and prepared foods. As expected, the available lysine content was lowest for the cereal-based prepared foods $\left(1.8-2.7 \mathrm{~g} \mathrm{~kg}^{-1} \mathrm{DM}\right)$, intermediate in the prepared foods containing cereals and legumes $\left(4 \cdot 2-4.9 \mathrm{~g} \mathrm{~kg}^{-1} \mathrm{DM}\right)$ and highest in the legume-based prepared foods $\left(9 \cdot 7-12.7 \mathrm{~g} \mathrm{~kg}^{-1}\right.$ $\mathrm{DM})$. For the cereals and legume ingredients respectively, the range in available lysine content was small with a 1.6-fold and 1.5-fold difference in the available lysine content across cereal ingredients and cereal-based prepared foods respectively and a 1.4-fold and 1.3-fold difference in available lysine content across legume ingredients and prepared foods respectively. The inclusion of legumes into cerealbased diets increased the available lysine content considerably (approximately double) and clearly fortification of cerealbased diets with legumes is a useful approach for increasing the lysine intakes of the Indian population.

Overall true ileal amino acid digestibility varied markedly across both ingredients and prepared foods and was often relatively low. It is clear that for even the most digestible ingredients and prepared foods amino acid digestion and absorption was far from complete and therefore must be taken into account when determining available amino acid content. Amino acid digestibility also varied considerably across amino acids within each ingredient and prepared food, with the difference between the lowest and highest digestibilities across amino acids within ingredients or prepared foods ranging from $12 \%$ units (88-100\%) for wheat flour to $85 \%$ units $(0-85 \%)$ for black gram beans for the ingredients and 15\% units (82-97\%) for lentil dal to $49 \%$ units (33-82\%) for rajmah. This highlights the potential error in using a single digestibility value (eg. crude protein digestibility) to predict amino acid digestibility in general. Protein digestibility-corrected amino acid scores (PDCAAS) are commonly calculated using a single digestibility factor (true faecal nitrogen digestibility). Depending on the limiting amino acid in each ingredient or prepared food, the use of true faecal nitrogen digestibility values could result in an inaccurate assessment of protein quality.

For the foods containing legumes, true ileal amino acid digestibility determined across all amino acids was lower for the food ingredients than for the prepared foods, which is most likely due to the presence of anti-nutritional factors ${ }^{(1)}$. For example, the overall mean amino acid digestibilities for 
Nes British Journal of Nutrition

Table 4. Mean $(n=5)$ true ileal amino acid digestibility ${ }^{1}(\%)$ for the eleven prepared Indian foods and ten raw Indian food ingredients ${ }^{1}$.

\begin{tabular}{|c|c|c|c|c|c|c|c|c|c|c|c|c|}
\hline \multirow[b]{2}{*}{ Amino acid } & \multicolumn{11}{|c|}{ Prepared Indian foods } & \multirow[b]{2}{*}{$\begin{array}{c}\text { Overall } \\
\text { SE }\end{array}$} \\
\hline & Wheat roti & $\begin{array}{l}\text { Cooked } \\
\text { rice }\end{array}$ & Maize roti & Dosa & Idli & $\mathrm{Naan}^{2}$ & $\begin{array}{l}\text { Mung } \\
\text { dal }\end{array}$ & Lentil dal & Sambar & $\begin{array}{l}\text { Chickpea } \\
\text { curry }\end{array}$ & Rajmah & \\
\hline Aspartic acid & 84 & 74 & 86 & 90 & 85 & 75 & 80 & 91 & 77 & 70 & 50 & 2.4 \\
\hline Threonine & 88 & 70 & 82 & 90 & 85 & 87 & 83 & 91 & 86 & 80 & 61 & 2.6 \\
\hline Serine & 93 & 72 & 90 & 91 & 86 & 91 & 86 & 95 & 88 & 84 & 64 & 1.8 \\
\hline Glutamic acid & 97 & 60 & 93 & 90 & 87 & 96 & 89 & 96 & 85 & 89 & 74 & 1.5 \\
\hline Alanine & 89 & 75 & 93 & 90 & 85 & 90 & 82 & 93 & 86 & 84 & 66 & $1 \cdot 7$ \\
\hline Valine & 91 & 78 & 90 & 92 & 89 & 89 & 88 & 95 & 90 & 83 & 68 & 1.9 \\
\hline Isoleucine & 95 & 75 & 91 & 91 & 87 & 93 & 85 & 95 & 88 & 82 & 72 & $2 \cdot 0$ \\
\hline Leucine & 98 & 82 & 96 & 95 & 93 & 97 & 94 & 98 & 95 & 88 & 76 & 1.3 \\
\hline Tyrosine & 91 & 81 & 94 & 90 & 88 & 90 & 87 & 96 & 91 & 88 & 74 & 1.8 \\
\hline Phenylalanine & 95 & 79 & 95 & 93 & 90 & 95 & 93 & 97 & 82 & 90 & 77 & 1.2 \\
\hline Histidine & 93 & 84 & 88 & 94 & 89 & 93 & 85 & 96 & 91 & 87 & 68 & 1.9 \\
\hline Lysine $^{3}$ & 91 & 96 & 90 & 95 & 91 & 89 & 95 & 97 & 94 & 90 & 81 & 1.4 \\
\hline Arginine & 89 & 84 & 89 & 92 & 89 & 92 & 87 & 97 & 91 & 91 & 79 & 1.4 \\
\hline Cysteine $^{4}$ & 74 & 48 & 77 & 82 & 63 & - & 70 & 88 & 79 & 72 & 33 & 4.4 \\
\hline Methionine ${ }^{4}$ & 89 & 54 & 96 & 92 & 81 & - & 93 & 100 & 98 & 94 & 82 & $2 \cdot 3$ \\
\hline Proline $^{4}$ & 85 & 75 & 89 & 97 & 88 & - & 85 & 97 & 94 & 92 & 72 & $2 \cdot 6$ \\
\hline Tryptophan $^{5}$ & - & - & 77 & - & - & - & 81 & 82 & 70 & 72 & 50 & 4.2 \\
\hline \multirow[t]{3}{*}{ Overall digestibility } & 91 & 74 & 89 & 91 & 86 & 91 & 86 & 95 & 87 & 84 & 67 & $2 \cdot 1$ \\
\hline & \multicolumn{10}{|c|}{ Indian food ingredients } & & \\
\hline & $\begin{array}{l}\text { Wheat } \\
\text { flour }\end{array}$ & Rice & $\begin{array}{l}\text { Maize } \\
\text { flour }\end{array}$ & $\begin{array}{c}\text { Black gram } \\
\text { beans }\end{array}$ & $\begin{array}{c}\text { Refined } \\
\text { flour }\end{array}$ & $\begin{array}{l}\text { Mung } \\
\text { beans }\end{array}$ & Lentils & Chickpeas & $\begin{array}{c}\text { Kidney } \\
\text { beans }\end{array}$ & $\begin{array}{l}\text { Pigeon } \\
\text { peas }\end{array}$ & $\begin{array}{c}\text { Overall } \\
\text { SE }\end{array}$ & \\
\hline Aspartic acid & 88 & 83 & 90 & 0 & 80 & 34 & 82 & 82 & 28 & 36 & 4.6 & \\
\hline Threonine & 92 & 81 & 84 & 22 & 86 & 43 & 89 & 83 & 38 & 53 & 4.7 & \\
\hline Serine & 98 & 88 & 93 & 20 & 96 & 63 & 92 & 86 & 47 & 54 & 3.0 & \\
\hline Glutamic acid & 99 & 84 & 96 & 20 & 98 & 54 & 89 & 89 & 43 & 49 & 3.0 & \\
\hline Alanine & 93 & 90 & 95 & 27 & 91 & 60 & 90 & 86 & 52 & 57 & 2.9 & \\
\hline Valine & 96 & 92 & 94 & 19 & 94 & 60 & 90 & 85 & 42 & 50 & 3.0 & \\
\hline Isoleucine & 98 & 90 & 95 & 14 & 96 & 52 & 87 & 83 & 34 & 46 & 3.4 & \\
\hline Leucine & 99 & 92 & 98 & 29 & 99 & 62 & 90 & 88 & 50 & 60 & $2 \cdot 7$ & \\
\hline Tyrosine & 97 & 89 & 95 & 44 & 95 & 69 & 86 & 90 & 47 & 62 & 3.2 & \\
\hline Phenylalanine & 98 & 90 & 97 & 20 & 97 & 60 & 89 & 89 & 43 & 49 & $3 \cdot 1$ & \\
\hline Histidine & 99 & 90 & 94 & 36 & 97 & 62 & 93 & 90 & 53 & 71 & 2.9 & \\
\hline Lysine $^{3}$ & 94 & 97 & 92 & 42 & 93 & 78 & 96 & 92 & 62 & 66 & $2 \cdot 5$ & \\
\hline Arginine & 93 & 89 & 91 & 46 & 88 & 70 & 94 & 93 & 66 & 70 & $2 \cdot 1$ & \\
\hline Cysteine $^{4}$ & 94 & 85 & 85 & 17 & 92 & 67 & 93 & 82 & 30 & 55 & 3.4 & \\
\hline Methionine $^{4}$ & 100 & 89 & 100 & 85 & 99 & 86 & 105 & 96 & 54 & 77 & 1.3 & \\
\hline Proline $^{4}$ & 100 & 91 & 94 & 55 & 99 & 64 & 99 & 94 & 28 & 74 & $2 \cdot 7$ & \\
\hline Tryptophan ${ }^{5}$ & 91 & - & 84 & - & 83 & 76 & 90 & 71 & - & - & 4.5 & \\
\hline Overall digestibility & 96 & 89 & 93 & 31 & 93 & 62 & 91 & 87 & 45 & 58 & $3 \cdot 1$ & \\
\hline
\end{tabular}

${ }_{1}^{1}$ Values were corrected for endogenous amino acid flows determined using the enzyme hydrolysed casein/ultrafiltration method ${ }^{(15)}$ and as reported by Rutherfurd and Moughan ${ }^{(14)}$. ${ }^{2}$ Insufficient digesta material for the determination of cysteine, methionine, proline and tryptophan.

${ }^{3}$ Based on reactive lysine determined using the guanidination method.

${ }^{4} n=5$ for all ingredients except wheat flour $(n=4)$ and kidney beans $(n=2)$ and all prepared foods except wheat roti $(n=4)$, dosa $(n=1)$ and idli $(n=2)$ where there was insufficient material to analyse digesta from all the rats.

${ }^{5}$ Insufficient digesta material for the determination of tryptophan. 
Table 5. Mean $(n=5)$ true ileal digestible amino acid contents ${ }^{1}\left(\mathrm{~g} \mathrm{~kg}^{-1} \mathrm{DM}\right)$ for the eleven prepared Indian foods and ten Indian food ingredients.

\begin{tabular}{|c|c|c|c|c|c|c|c|c|c|c|c|c|}
\hline \multirow[b]{2}{*}{ Amino acid } & \multicolumn{11}{|c|}{ Prepared Indian foods } & \multirow[b]{2}{*}{$\begin{array}{l}\text { Overall } \\
\text { SE }\end{array}$} \\
\hline & $\begin{array}{l}\text { Wheat } \\
\text { roti }\end{array}$ & $\begin{array}{l}\text { Cooked } \\
\text { rice }\end{array}$ & $\begin{array}{l}\text { Maize } \\
\text { roti }\end{array}$ & Dosa & Idli & $\mathrm{Naan}^{2}$ & $\begin{array}{l}\text { Mung } \\
\text { dal }\end{array}$ & $\begin{array}{l}\text { Lentil } \\
\text { dal }\end{array}$ & Sambar & $\begin{array}{c}\text { Chickpea } \\
\text { curry }\end{array}$ & Rajmah & \\
\hline Aspartic acid & $6 \cdot 0$ & 4.5 & 5.5 & $11 \cdot 8$ & $13 \cdot 0$ & $5 \cdot 8$ & $22 \cdot 6$ & $23 \cdot 0$ & $16 \cdot 7$ & $15 \cdot 2$ & 14.4 & 0.33 \\
\hline Threonine & 3.6 & $1 \cdot 7$ & $3 \cdot 0$ & 3.9 & $4 \cdot 3$ & 4.4 & $7 \cdot 2$ & 7.5 & $6 \cdot 5$ & $5 \cdot 5$ & $6 \cdot 4$ & 0.13 \\
\hline Serine & $5 \cdot 2$ & $2 \cdot 3$ & 3.9 & 4.9 & 5.5 & $6 \cdot 6$ & 8.9 & $9 \cdot 2$ & $8 \cdot 3$ & $7 \cdot 1$ & $8 \cdot 6$ & 0.11 \\
\hline Glutamic acid & 39.5 & $7 \cdot 2$ & 17.9 & $18 \cdot 0$ & $19 \cdot 8$ & $52 \cdot 4$ & $35 \cdot 0$ & 33.4 & 37.9 & $25 \cdot 5$ & $27 \cdot 8$ & 0.34 \\
\hline Alanine & $4 \cdot 2$ & $2 \cdot 9$ & 6.4 & $4 \cdot 7$ & $5 \cdot 1$ & $4 \cdot 5$ & $7 \cdot 4$ & $7 \cdot 2$ & $6 \cdot 9$ & $5 \cdot 8$ & $6 \cdot 2$ & 0.09 \\
\hline Valine & 5.4 & $3 \cdot 2$ & $4 \cdot 1$ & $6 \cdot 1$ & $6 \cdot 8$ & 6.5 & $10 \cdot 4$ & $9 \cdot 2$ & $8 \cdot 1$ & $6 \cdot 7$ & 8.5 & 0.13 \\
\hline Isoleucine & $4 \cdot 2$ & $2 \cdot 0$ & $2 \cdot 9$ & $4 \cdot 3$ & 4.8 & $5 \cdot 3$ & $7 \cdot 8$ & 7.5 & $6 \cdot 3$ & $5 \cdot 9$ & $6 \cdot 6$ & 0.11 \\
\hline Leucine & $5 \cdot 6$ & 3.1 & $8 \cdot 3$ & $6 \cdot 0$ & 7.4 & $7 \cdot 8$ & $12 \cdot 6$ & $11 \cdot 2$ & $10 \cdot 8$ & $9 \cdot 4$ & $11 \cdot 1$ & 0.10 \\
\hline Tyrosine & 2.9 & $2 \cdot 1$ & $3 \cdot 2$ & 3.5 & $3 \cdot 3$ & $4 \cdot 6$ & 5.9 & 5.5 & $5 \cdot 1$ & 4.5 & $5 \cdot 8$ & 0.07 \\
\hline Phenylalanine & $5 \cdot 3$ & $2 \cdot 6$ & $4 \cdot 1$ & $5 \cdot 5$ & $6 \cdot 4$ & 6.9 & 11.7 & $9 \cdot 1$ & $16 \cdot 3$ & $8 \cdot 7$ & 9.9 & 0.09 \\
\hline Histidine & 2.5 & $1 \cdot 2$ & $2 \cdot 1$ & $2 \cdot 6$ & $2 \cdot 9$ & $2 \cdot 9$ & $5 \cdot 0$ & $4 \cdot 3$ & $6 \cdot 1$ & $3 \cdot 6$ & $4 \cdot 2$ & 0.06 \\
\hline Arginine & 4.9 & $4 \cdot 1$ & 3.5 & $6 \cdot 3$ & 6.9 & $5 \cdot 5$ & $12 \cdot 1$ & $17 \cdot 6$ & $11 \cdot 1$ & $13 \cdot 1$ & $12 \cdot 6$ & 0.11 \\
\hline Cysteine $^{3}$ & 3.2 & 1.0 & 1.8 & $2 \cdot 1$ & 1.0 & - & 1.4 & 3.0 & $2 \cdot 1$ & $2 \cdot 9$ & 0.7 & 0.13 \\
\hline Methionine $^{3}$ & 2.9 & 1.4 & $2 \cdot 3$ & $3 \cdot 8$ & $2 \cdot 1$ & - & $3 \cdot 3$ & $2 \cdot 4$ & $3 \cdot 0$ & 3.5 & $2 \cdot 6$ & 0.13 \\
\hline Proline $^{4}$ & 11.3 & $2 \cdot 9$ & 7.7 & $5 \cdot 7$ & 3.9 & - & $6 \cdot 8$ & $8 \cdot 6$ & $8 \cdot 4$ & $7 \cdot 0$ & $6 \cdot 6$ & 0.32 \\
\hline \multirow[t]{2}{*}{ Tryptophan ${ }^{4}$} & $2 \cdot 4$ & - & 0.7 & - & - & - & $2 \cdot 6$ & 1.6 & 1.3 & $1 \cdot 8$ & $1 \cdot 6$ & 0.07 \\
\hline & \multicolumn{10}{|c|}{ Indian food ingredients } & & \\
\hline Amino acid & $\begin{array}{r}\text { Wheat } \\
\text { flour }\end{array}$ & Rice & $\begin{array}{c}\text { Maize } \\
\text { flour }\end{array}$ & $\begin{array}{c}\text { Black gram } \\
\text { beans }\end{array}$ & $\begin{array}{c}\text { Refined } \\
\text { flour }\end{array}$ & $\begin{array}{l}\text { Mung } \\
\text { beans }\end{array}$ & Lentils & Chickpeas & $\begin{array}{l}\text { Kidney } \\
\text { beans }\end{array}$ & $\begin{array}{l}\text { Pigeon } \\
\text { peas }\end{array}$ & $\begin{array}{c}\text { Overall } \\
\text { SE }\end{array}$ & \\
\hline Aspartic acid & $5 \cdot 3$ & $4 \cdot 1$ & 4.9 & 0 & $3 \cdot 7$ & $8 \cdot 0$ & $19 \cdot 8$ & $22 \cdot 7$ & $8 \cdot 0$ & $7 \cdot 7$ & 0.97 & \\
\hline Threonine & $3 \cdot 1$ & $1 \cdot 7$ & $2 \cdot 7$ & 1.8 & 2.5 & $3 \cdot 3$ & 7.5 & 7.4 & $4 \cdot 0$ & 4.4 & 0.28 & \\
\hline Serine & $6 \cdot 3$ & 3.0 & 4.7 & $2 \cdot 9$ & $5 \cdot 5$ & $7 \cdot 8$ & $10 \cdot 9$ & $11 \cdot 0$ & $6 \cdot 8$ & $6 \cdot 3$ & 0.30 & \\
\hline Glutamic acid & $36 \cdot 9$ & 8.8 & $17 \cdot 3$ & 8.9 & $40 \cdot 7$ & $20 \cdot 2$ & $31 \cdot 2$ & $35 \cdot 0$ & $16 \cdot 6$ & $24 \cdot 1$ & 1.05 & \\
\hline Alanine & $4 \cdot 0$ & $3 \cdot 3$ & $7 \cdot 2$ & 0 & $3 \cdot 3$ & $6 \cdot 2$ & 8.4 & 8.9 & $5 \cdot 4$ & $5 \cdot 8$ & 0.22 & \\
\hline Valine & 5.5 & 3.6 & 4.4 & $2 \cdot 9$ & $4 \cdot 8$ & $6 \cdot 2$ & $8 \cdot 6$ & $8 \cdot 4$ & $5 \cdot 2$ & $4 \cdot 8$ & 0.30 & \\
\hline Isoleucine & 4.0 & $2 \cdot 0$ & $3 \cdot 1$ & $2 \cdot 6$ & $3 \cdot 6$ & 4.4 & $7 \cdot 1$ & $7 \cdot 9$ & $3 \cdot 4$ & $3 \cdot 6$ & 0.27 & \\
\hline Leucine & 5.5 & 5.4 & 9.5 & 1.4 & 4.4 & $9 \cdot 4$ & $12 \cdot 0$ & $13 \cdot 3$ & $7 \cdot 6$ & $7 \cdot 7$ & 0.35 & \\
\hline Tyrosine & 3.9 & $2 \cdot 2$ & 3.7 & $5 \cdot 2$ & 3.8 & $3 \cdot 6$ & $4 \cdot 8$ & $5 \cdot 6$ & $2 \cdot 8$ & 3.5 & 0.14 & \\
\hline Phenylalanine & $5 \cdot 3$ & $2 \cdot 5$ & 4.5 & $2 \cdot 4$ & $5 \cdot 0$ & 7.9 & $9 \cdot 1$ & $12 \cdot 0$ & $5 \cdot 7$ & $11 \cdot 6$ & 0.36 & \\
\hline Histidine & $2 \cdot 3$ & $1 \cdot 0$ & $2 \cdot 2$ & $2 \cdot 9$ & 1.9 & 3.9 & 4.5 & $5 \cdot 3$ & $3 \cdot 4$ & $5 \cdot 5$ & 0.14 & \\
\hline Arginine & $5 \cdot 7$ & $4 \cdot 3$ & $4 \cdot 3$ & $2 \cdot 4$ & $4 \cdot 0$ & $10 \cdot 8$ & $20 \cdot 5$ & $21 \cdot 7$ & $9 \cdot 8$ & $10 \cdot 5$ & 0.23 & \\
\hline Cysteine $^{3}$ & 3.8 & $2 \cdot 1$ & $2 \cdot 2$ & 0.4 & 3.5 & $1 \cdot 6$ & $3 \cdot 0$ & $4 \cdot 2$ & 0.9 & 1.5 & 0.08 & \\
\hline Methionine $^{3}$ & $2 \cdot 7$ & $2 \cdot 6$ & $2 \cdot 5$ & 4.7 & $2 \cdot 6$ & $3 \cdot 6$ & $2 \cdot 3$ & 4.7 & $2 \cdot 2$ & 2.5 & 0.04 & \\
\hline Proline $^{3}$ & 14.4 & 3.3 & $8 \cdot 1$ & $6 \cdot 2$ & $14 \cdot 3$ & 6.8 & $9 \cdot 2$ & 9.9 & $2 \cdot 6$ & $8 \cdot 2$ & 0.21 & \\
\hline Tryptophan ${ }^{4}$ & $2 \cdot 1$ & - & 0.8 & - & 1.6 & $2 \cdot 9$ & $2 \cdot 2$ & $2 \cdot 3$ & - & - & 0.09 & \\
\hline
\end{tabular}

${ }^{1}$ True ileal digestible lysine content is presented in Table 3 as the true ileal digestible reactive lysine content.

$3 n=5$ for all ingredients except wheat flour $(n=4)$ and kidney beans $(n=2)$ and all prepared foods except wheat roti $(n=4)$, dosa $(n=1)$ and idli $(n=2)$ where there was insufficient material to analyse digesta from all the rats. Insufficient digesta material for the determination of tryptophan. 
mung dal, sambar, and rajmah were markedly higher than for their main ingredients (mung beans, pigeon peas and kidney beans). Similarly, Wu et al. ${ }^{(22)}$ reported true faecal protein digestibility values of 16 and $79 \%$ respectively for raw kidney beans and kidney beans cooked at $100^{\circ} \mathrm{C}$ for $2 \mathrm{~h}$. The increase in the mean amino acid digestibility is most likely due to the destruction of anti-nutritional factors present in the legume ingredients during cooking ${ }^{(23)}$. For the cerealbased ingredients and prepared foods, wheat roti, cooked rice, maize roti, naan were more poorly digested than their respective major ingredients wheat flour, rice, maize flour, wheat flour. Kubota et al. ${ }^{(24)}$ have also reported that cooking reduces the digestion of prolamin, a major storage protein in rice. The decrease in mean amino acid digestibility observed for the cereal-based prepared foods is possibly due to Maillard-type reactions occurring during cooking ${ }^{(6)}$ and the subsequent formation of indigestible limit peptides ${ }^{(25)}$. For lentil dal and chickpea curry each made from lentils and chickpeas respectively, the overall mean amino acid digestibility of the prepared food was similar to that of the respective major ingredients.

There was considerable variation in the true ileal digestible amino acid contents for each amino acid, including lysine, across both the prepared foods (on average a 4.6-fold difference) and food ingredients (on average a 5.4-fold difference). As expected the amino acid profile of the prepared foods generally reflected that observed for the main ingredients included in each of the prepared foods.

Diet surveys conducted by the National Nutrition Monitoring Bureau (NNMB) of India during 2001-2002 $2^{(17)}$ revealed that among 1-6 year-old children, the consumption of various foods like cereals and pulses was less than the recommended levels. The intake among the adults was higher, where the recommended intake of cereals was met, but the intake of legumes was still inadequate. Furthermore, while adults received $80-90 \%$ of the recommended dietary protein intake only $30 \%$ of children consumed protein adequate diets. The net availability (per capita per day) of cereals in India has increased from 394.9 g in 1951 to $439.3 \mathrm{~g}$ in 2007 but at the same time the net availability of legumes which are a significant source of lysine for Indians has declined from $60.7 \mathrm{~g}$ in 1951 to $29.4 \mathrm{~g}$ in $2007^{(18)}$. In an attempt to put the results of the present study into context, the available lysine intake of the Indian population for a range of commonly consumed prepared food combinations based on the prepared foods tested in the present study was estimated and is presented in Table 6. The daily lysine intakes were estimated in two ways, firstly, based on the reported average daily energy intake of the Indian population $\left(2034 \mathrm{kcal} \mathrm{day}^{-1}\right)^{(26)}$ and secondly based on cereal and legume supply data ${ }^{(18)}$

Table 6. Estimated daily lysine intake $\left(\mathrm{g} \mathrm{day}^{-1}\right)$ and lysine adequacy for the Indian population receiving a diet derived from selected foods tested in this study.

\begin{tabular}{|c|c|c|c|c|c|c|c|c|}
\hline \multirow[b]{2}{*}{$\begin{array}{l}\text { Percentage of legume-based food } \\
\text { to cereal-based food }\end{array}$} & \multicolumn{4}{|c|}{ Based on cereal and legume supply in India } & \multicolumn{4}{|c|}{ Based on reported daily energy intakes } \\
\hline & \multicolumn{2}{|c|}{$10: 90$} & \multicolumn{2}{|c|}{$20: 80$} & Lys intake $^{2}$ & Adequacy $^{3}$ & \multicolumn{2}{|c|}{$20: 80$} \\
\hline Sambar/idli & $2 \cdot 24$ & 1.05 & $2 \cdot 42$ & $1 \cdot 14$ & $2 \cdot 51$ & $1 \cdot 18$ & $2 \cdot 70$ & $1 \cdot 27$ \\
\hline Sambar/dosa & 1.90 & 0.90 & $2 \cdot 04$ & 0.96 & 1.96 & 0.93 & $2 \cdot 11$ & 0.99 \\
\hline Mung dal/wheat roti & 1.35 & 0.64 & 1.59 & 0.75 & 1.50 & 0.71 & $1 \cdot 76$ & 0.83 \\
\hline Lentil dal/wheat roti & $1 \cdot 38$ & 0.65 & 1.66 & 0.78 & 1.53 & 0.72 & 1.83 & 0.87 \\
\hline Chickpea curry/wheat roti & $1 \cdot 32$ & 0.62 & 1.53 & 0.72 & 1.46 & 0.69 & 1.68 & 0.79 \\
\hline Rajmah/wheat roti & $1 \cdot 29$ & 0.61 & 1.47 & 0.69 & 1.44 & 0.68 & 1.64 & 0.77 \\
\hline Mung dal/cooked rice & $1 \cdot 27$ & 0.60 & 1.69 & 0.80 & 1.44 & 0.68 & 1.91 & 0.90 \\
\hline Lentil dal/cooked rice & $1 \cdot 33$ & 0.63 & $1 \cdot 81$ & 0.85 & $1 \cdot 51$ & 0.71 & 2.03 & 0.96 \\
\hline Sambar/cooked rice & $1 \cdot 17$ & 0.55 & 1.52 & 0.72 & $1 \cdot 34$ & 0.63 & $1 \cdot 72$ & 0.81 \\
\hline Chickpea curry/cooked rice & $1 \cdot 22$ & 0.58 & 1.59 & 0.75 & $1 \cdot 38$ & 0.65 & $1 \cdot 77$ & 0.83 \\
\hline Mung dal/maize roti & 0.99 & 0.47 & $1 \cdot 24$ & 0.58 & 1.08 & 0.51 & $1 \cdot 34$ & 0.63 \\
\hline Lentil dal/maize roti & 1.02 & 0.48 & $1 \cdot 30$ & 0.62 & $1 \cdot 11$ & 0.52 & 1.41 & 0.67 \\
\hline Chickpea curry/maize roti & 0.97 & 0.46 & $1 \cdot 19$ & 0.56 & 1.05 & 0.50 & $1 \cdot 28$ & 0.60 \\
\hline Rajmah/maize roti & 0.94 & 0.44 & $1 \cdot 12$ & 0.53 & 1.02 & 0.48 & $1 \cdot 22$ & 0.58 \\
\hline Mung dal/naan & $1 \cdot 13$ & 0.53 & 1.35 & 0.64 & $1 \cdot 20$ & 0.57 & 1.44 & 0.68 \\
\hline Lentil dal/naan & $1 \cdot 16$ & 0.55 & 1.41 & 0.67 & $1 \cdot 23$ & 0.58 & 1.50 & 0.71 \\
\hline Chickpea curry/naan & $1 \cdot 11$ & 0.52 & $1 \cdot 30$ & 0.62 & $1 \cdot 18$ & 0.56 & 1.38 & 0.65 \\
\hline Rajmah/naan & 1.08 & 0.51 & $1 \cdot 24$ & 0.59 & $1 \cdot 15$ & 0.54 & 1.33 & 0.63 \\
\hline
\end{tabular}

${ }^{1}$ Based on a daily food intake of $468.7 \mathrm{~g} \mathrm{day}^{-1}\left(439.3 \mathrm{~g}_{\text {day }}{ }^{-1}\right.$ of cereals and $29.4 \mathrm{~g}_{\text {day }}{ }^{-1}$ of legumes) ${ }^{(18)}$ and assuming a DM content of $90 \%$ calculated as follows:

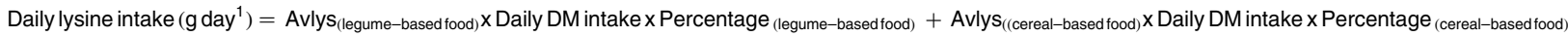

Where Avlys is the determined available lysine content $\left(\mathrm{g} \mathrm{g}^{-1}\right)$ of the prepared food, percentage is the percentage of either the legume-based prepared food or cereal-based prepared food in the combined food and daily DM intake $=421.8 \mathrm{~g} \mathrm{DM}^{-1 a y}{ }^{-1}\left(468 \cdot 7 \mathrm{~g} \mathrm{day}^{1} \times 90 \% \mathrm{DM}\right)$.

${ }^{2}$ Based on the reported daily energy intake of $2034 \mathrm{kcal}^{-126)}$ and calculated as follows:

Daily lysine intake $=$ Avlys $_{(\text {legume-based food })} \times$ Daily DM intake Percentage $_{(\text {legume-based food })}+$ Avlys $_{(\text {cereal-based food })} \times$ Daily DM intake $\times$ Percentage $_{(\text {cereal-based food })}$

Where Avlys is the determined available lysine content $\left(\mathrm{g} \mathrm{g}^{-1}\right)$ of the prepared food, percentage is the percentage of either the legume-based prepared food or cereal-based prepared food in the combined food and daily DM intake is calculated as follows:

Daily DM intake $=$ Daily energy intake $\left(\mathrm{kcal} \mathrm{day}^{-1}\right)^{(26)} /$ Energy content of the combined food $\left(\mathrm{kcal} \mathrm{g}^{-1} \mathrm{DM}\right)$

${ }^{3}$ Adequacy was calculated for a $70 \mathrm{~kg}$ adult based on a lysine requirement of $30 \mathrm{mg} \mathrm{kg}^{-1}$ day $^{-1(27)}$ as follows:

Adequacy $=$ Lysine intake $\left(\mathrm{g} \mathrm{day}^{-1}\right) /$ Lysine requirement $\left(\mathrm{g} \mathrm{day}^{-1}\right)$

${ }^{4}$ Percentage of each prepared food in the combined food and based on the wet weight. 
and assuming $10 \%$ food wastage. In both cases it was assumed that for each day each meal consisted of a legumebased prepared food and a cereal-based prepared food (for example, cooked rice with sambar) the proportions of which were assumed to be between $10 \%$ to $20 \%$ legumebased prepared food and correspondingly between $90 \%$ to $80 \%$ cereal-based prepared food (these figures were based on the relative legume and cereal availability in India ${ }^{(18)}$ ). A similar analysis (data not shown) was conducted for the sulphur amino acids (methionine plus cysteine) which tend to be first limiting in legumes. For a seventy kilogram adult human, the lysine requirement is $2 \cdot 12 \mathrm{~g}^{\mathrm{day}^{-1(27)}}{ }^{-}$and the methionine plus cysteine requirement $0.98 \mathrm{~g} \mathrm{day}^{-1(27)}$; however, the estimated daily lysine intake for all of the prepared food combinations, with the exception of sambar/idli was lower than $2.12 \mathrm{~g} \mathrm{day}^{-1}$ ranging from $0.94 \mathrm{~g} \mathrm{day}^{-1}$ for rajmah/maize roti (10:90) to $2.04 \mathrm{~g} \mathrm{day}^{-1}$ for sambar/dosa (20:80) when based on cereal and legume availability per capita and ranging from $1.02 \mathrm{~g} \mathrm{day}^{-1}$ for rajmah/maize roti (10:90) to $2 \cdot 1 \mathrm{~g} \mathrm{day}^{-1}$ for sambar/dosa (20:80) when based on daily energy intake. In contrast, the daily intake of sulphur amino acids estimated based on the daily energy intake of the Indian population ranged from $1.30 \mathrm{~g} \mathrm{day}^{-1}$ for sambar/ cooked rice (10:90) to $2 \cdot 88 \mathrm{~g} \mathrm{day}^{-1}$ for chickpea curry/wheat roti (10:90) and would be sufficient to meet the daily methionine plus cysteine requirement for a $70 \mathrm{~kg}$ man for all of the prepared food combinations examined. Although it is recognised that it is unlikely that Indians will consume the same prepared food combination for each meal in a day, consumption of any of the prepared food combinations, excluding sambar/idli, would lead to an insufficient daily lysine intake and in many cases supplying less than three quarters of the daily lysine requirement. The similar outcome, as to whether analysis was based on food supply data or reported energy intakes, gives some confidence in the data. For the scenario above both protein and energy would be limiting. However, even if food intakes were sufficient to meet energy requirements it was calculated that lysine would still be limiting for between $40-80 \%$ of the food combinations evaluated as part of this study.

\section{Conclusion}

The available lysine content was highly variable across ingredients and prepared foods. In addition, digestible total lysine overestimated available lysine (digestible reactive lysine) for many of the ingredients and prepared foods. This has important implications for dietary protein quality assessment. Available (true ileal digestible reactive) lysine values are generally likely to be lower than true faecal lysine digestibility values because faecal lysine digestibility usually overestimates ileal lysine digestibility and digestible total lysine often over estimates digestible reactive (available) lysine. True ileal amino acid digestibility varied widely both across ingredients and prepared foods for each amino acid and also across amino acids within each ingredient and prepared food. True ileal nitrogen digestibility was a poor predictor of amino acid digestibility for many amino acids in the ingredients and prepared foods tested in this study. Amino acid digestibility was often far less than complete and consequently amino acid digestibility must be taken into account when assessing the protein quality of poorer quality foods and ingredients such as those often consumed in developing countries such as India.

\section{Acknowledgements}

We acknowledge the support and advice of Dr G SarwarGilani in the conduct of this work. We also acknowledge the Riddet Institute, Massey University, Palmerston North for financial support.

SR co-designed the study, ran the animal trials and laboratory analysis and co-wrote the manuscript. KB co-designed the study and arranged for the collection and preparation of the samples and co-wrote the manuscript. PM co-designed the study and co-wrote the manuscript. The authors state that there are no conflicts of interest. Funding for the work was provided by the Riddet Institute.

\section{References}

1. Gilani GS, Cockell KA \& Sepehr E (2005) Effects of antinutritional factors on protein digestibility and amino availability in foods. $J$ AOAC Int $\mathbf{8 8}, 967-987$.

2. Rowan AM, Moughan PJ, Wilson MN, et al. (1994) Comparison of the ileal and faecal digestibility of dietary amino acids in adult humans and evaluation of the pig as a model animal for digestion studies in man. Br J Nutr 71, 29-42.

3. Ratriyanto A, Mosenthin R, Jezierny D, et al. (2010) Effect of graded levels of dietary betaine on ileal and total tract nutrient digestibilities and intestinal bacterial metabolites in piglets. J Anim Physiol Nutr 94, 788-796.

4. Moughan PJ (2003) Amino acid availability: aspects of chemical analysis and bioassay methodology. Nutr Res Rev 16, 127-141.

5. Fuller M (2012) Determination of protein and amino acid digestibility in foods including implications of gut microbial amino acid synthesis. Br J Nutr 108(Suppl 2), S238-S246.

6. Hurrell RF \& Carpenter KJ (1981) The estimation of available lysine in foodstuffs after Maillard reactions. Prog Food Nutr Sci 5, 159-176.

7. Kurpad AV, Raj T, El-Khoury AE, et al. (2000) Lysine requirements of healthy adult Indian subjects, measured by an indicator amino acid balance technique. Amer J Clin Nutr 73, 900-907.

8. Kurpad AV, Regan MM, Raj T, et al. (2003) Lysine requirement of chronically undernourished adult Indian subjects, measured by the $24 \mathrm{~h}$ indicator amino acid oxidation and balance technique. Amer J Clin Nutr 77, 101-108.

9. Moughan PJ \& Rutherfurd SM (1996) A new method for determining digestible reactive lysine in foods. J Agric Food Chem 44, 2202-2209.

10. Rutherfurd SM, Moughan PJ \& Morel PCH (1997) Assessment of the true ileal digestibility of reactive lysine as a predictor of lysine uptake from the small intestine of the growing pig. J Agric Food Chem 45, 4378-4383.

11. National Research Council (1995) Nutrient requirement of the laboratory rat. In Nutrient Requirements of Laboratory Animals, $4^{\text {th }}$ ed., Washington National Academy of Sciences. 
12. AOAC (1995) Official Methods of Analysis of AOAC International, $16^{\text {th }}$ ed. Gaithersburg, MD: AOAC.

13. Short FJ, Gorton P, Wiseman J, et al. (1996) Determination of titanium dioxide added as an inert marker in chicken digestibility studies. Anim Feed Sci Technol 59, 215-221.

14. Rutherfurd SM \& Moughan PJ (2003) The rat as a model animal for the growing pig in determining ileal amino acid digestibility in soya and milk proteins. J Anim Physiol Anim Nutr 87, 292-300.

15. Moughan PJ, Darragh AJ, Smith WC, et al. (1990) The efficacy of trichloroacetic and perchloric acids as precipitants of protein in endogenous digesta collected from the distal ileum of the rat. $J$ Sci Food Agric 52, 13-21.

16. SAS Institute Inc. (1999) SAS User's Guide: Statistics. Version 8.02. Cary, NC: SAS Institute Inc.

17. Brahmam SNV (2007) National Nutrition Monitoring Bureau in India - An Overview. Ind J Community Med 32, 7-9.

18. Ghatak S (2009) Present status of Indian Agriculture. eIndia 2007, September 15.

19. Rutherfurd SM, Torbatinejad NM \& Moughan PJ (2006) Available (ileal digestible reactive) lysine in selected cerealbased food products. J Agric Food Chem 54, 9453-9457.

20. Rutherfurd SM \& Moughan PJ (2005) Digestible reactive lysine in selected milk-based products. J Dairy Sci $\mathbf{8 8}$, $40-48$.
21. Rutherfurd SM, Moughan PJ \& van Osch L (1997) Digestible reactive lysine in processed feedstuffs-Application of a new bioassay. J Agric Food Chem 45, 1189-1194.

22. Wu W, Williams WP, Kunkel ME, et al. (1995) True protein digestibility and digestibility-corrected amino acid score of red kidney beans (Phaseolus vulgaris L.). J Agric Food Chem 43, 1295-1298.

23. Uebersax MA, Ruengsakulrach S \& Occena LG (1991) Strategies and procedures for processing dry beans. Food Technol 49, 104-108.

24. Kubota M, Saito Y, Masumura T, et al. (2011) Rice prolamin/ protein body-I becomes indigestible after cooking. Proceedings of the International Symposium for Dietary Protein for Human Health. Auckland, New Zealand, pp 105. ISBN: 978-0-473-18552-7.

25. Moughan PJ, Gall MPJ \& Rutherfurd SM (1996) Absorption of lysine and deoxyketosyllysine in an early Maillard browned casein by the growing pig. J Agric Food Chem 44, $1520-1525$

26. Deaton A \& Drèze J (2009) Food and Nutrition in India: Facts and interpretations. Economic \& Political Weekly 44, 42-65.

27. World Health Organization (2007) Protein and Amino Acid Requirements in Human Nutrition. Joint FAO/WHO/UNU Expert Consultation. WHO Technical Reports Series no. 935. Geneva: WHO. 